\title{
Perception of Edible Insect and Insect Foods among Adults
}

Youn-Jung $\mathrm{Kim}^{1}$, Yookyung Kim² , Jung-Soon $\mathrm{Han}^{3 *}$

${ }^{1}$ Department of Human Ecology, Korea University, Seoul, Korea

${ }^{2}$ Department of Home Economics Education, College of Education, Korea University, Seoul, Korea

${ }^{3}$ Research Institute of Human Ecology, Korea University, Seoul, Korea

*Corresponding author: Jung-Soon Han, Research Institute of Human Ecology, Korea University, 145 Anam-ro, Seongbukgu, Seoul 02841, Korea

Tel.: +82 232901672

Email: yohwa0960@korea.ac.kr

Received January 06, 2020

Revised February 06, 2020

Accepted February 17, 2020

Published March 30, 2020

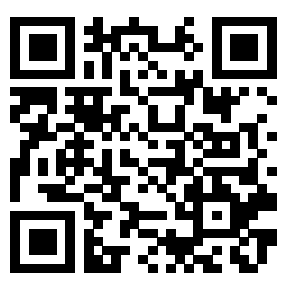

\begin{abstract}
Purpose: This study was conducted to investigate the awareness of edible insects and insect foods among Korean adults and to use the findings as basic data in program development research to improve the awareness of edible insects. Methods: A survey was conducted with 387 adults aged 21-64 years who were living in Korea. Data analysis was performed using SPSS statistics 24 . The perception and experiences related to eating edible insects were analyzed using frequency analysis; and chi-square test. Results: In total, 311 participants (80.40\%) responded that edible insects are emerging as food sources and most people are aware of the potential of food insects as a future food resource. The number of participants aware of edible insects is likely to be $311(80.40 \%)$, whereas that of participants unaware of them is likely $<79(19.60 \%)$. Further, $181(46.77 \%)$ respondents had eaten edible insects and $220(56.85 \%)$ had never eaten insect foods. The number of participants who used edible insects for food purposes was 107 (59.12\%), among whom 81 (44.75\%) had eaten silkworm pupa. When selecting edible insects for consumption, sensory evaluation was considered important by participants. Conclusion: This study suggests that the commercialization and industrialization of edible insects, which are emerging as future food resources, will require the development of dietary education programs to improve the awareness of edible insects.
\end{abstract}

Keywords: Edible insects, Awareness, Adults, Edible insect food, Dietary education program

\section{Introduction}

전 세계 인구는 과학과 의료기술, 식품산업의 혁신적 발달로 지속 적으로 증가하고 있으며, 수명연장으로 인한 노령인구가 급증하고 있고 기후와 환경 변화 등으로 인구증가에 비해 식량 수급이 제대 로 되지 않고 있으며, 특히 육류 등의 동물성 단백질 식품의 공급부 족과 안전성에 대해서도 각종 문제가 제기 되고 있다(Alston et al., 2009). 이러한 식량 수급 문제 중 새로운 식량자원으로서 뿐 아니 라 양질의 동물성 단백질 공급 부족을 해결할 수 있는 방안의 하나 로 세계 여러 지역에서 오래 전부터 전통적으로 식용해온 식용곤충 이 대안으로 제시되고 있다(Hegsted et al., 1993). 식용곤충은 동 물성 단백질의 주요 공급원인 가축에 비해 ㅉㄼㄼ은 생애주기를 가지고 있어 공급이 용이한 식량 자원이며(Chung et al., 2013), 적은 양의 사료와 물, 공간이용으로 경제적 비용 절감 효과와 농약이나 항생제
를 사용하지 않고 온실가스를 적게 방출하므로 자연 그대로의 환경 을 유지할 수 있어 생태계를 보존하여 환경 오염을 줄일 수 있다는 장점이 있다(Arsenault et al., 2017). 식용곤충은 단백질 함량이 높 고 특히 근육관련 아미노산 함량이 많으며, 불포화 지방산, 미량 무 기질 등이 풍부할 뿐 아니라 항산화 영양소(Chong et al., 2017)도 풍부하다. 또한 여러 가지 생리기능 활성물질(Na et al., 2016; No, 2010)을 많이 함유하고 있어 고령화 사회에서 노화가 진행됨에 따 라 근 감소로 인하여 단백질 섭취가 중요한 노인들이나 과잉의 육 류섭취로 인해 혈중 지질의 증가가 우려되는 사람들과 건강을 중요 시 하는 현대인들의 요구에 부합되는 적합한 식량대체자원으로 식 품소재나 각종 기능성 식품으로(Hwang \& Choi, 2015; Kim et al., 2014)으로 연구되고 있다. 이러한 식용곤충은 최근에는 운동선수 를 위한 단백질 보충식품(Min et al., 2016), 노인과 환자를 위한 영 양 보충식(Kang et al., 2017; Kim et al., 2015), 의약품과 기능성 
화장품의 신소재 원료로 연구되는 등 적용범위가 넓어지고 활용도 다양해지고 있다(Na et al., 2016). 우리나라에서도 이미 오래 전부 터 메뚜기, 개구리, 번데기, 누에 등 다양한 곤충들을 식용으로 섭취 해 왔으며 특히 메뚜기는 튀김으로 많이 즐겼고, 양잠 산업이 급속 도로 성장했던 1960년대에는 번데기를 삶아 먹는 경우가 많았으며 아직도 길거리 음식으로 이를 즐기는 사람들을 적지 않게 볼 수 있 다(Chung et al., 2013). 우리나라는 2010년 농림축산식품부가 곤 충산업 성장의 필요성을 인지하고 '곤충 산업의 육성 및 지원에 관한 법률'을 제정하고, '제 1 차 곤충 산업 육성 5 개년 종합 계획'을 실시하 면서 곤충 산업이 급속도로 성장하고 있다. 2016년에는 '제 2 차 곤충 산업 육성 5 개년 계획'이 시작되었고, 식용 곤충 산업 시장의 형성과 성장을 지원하기 위해 다양한 노력이 지속되고 있다. 2015년 곤충 유통 업체의 곤충 취급 비중을 보면 애완 학습 곤충이 $85.7 \%$, 식용 곤충의 취급 비중은 $8.9 \%$ 로 다소 적었지만, 매출액은 $20.8 \%$ 로 취 급 비중 대비 매출액이 높은 것으로 나타나 식용 곤충의 부가가치가 상당히 높다고 평가할 수 있다(Jung et al., 2018). 이렇듯 식용곤충 은 학습, 애완, 약리작용 등의 용도로 활용되고는 있으나 아직까지 식용곤충에 대한 외형이나 인식부족으로 식용이 대중화되거나 식품 등으로의 실용화가 많이 이루어지고 있지는 않은 실정이다. 국내에 서 이루어진 식용곤충 인식에 대한 연구도 대부분이 대학생을 대상 으로 하고 지역이 지방으로 한정적인 경우가 많아 연구결과를 활용 하기에는 한계가 있다. 이에 본 연구는 국내에 거주하고 있는 성인 (20세 이상-65세 미만) 남녀를 대상으로 식용곤충과 식용곤충 이용 식품에 대한 인식을 조사하여 향후 식용곤충 인식개선을 위한 식생 활교육프로그램 개발 연구의 기초자료로 활용하고자 한다.

\section{Methods}

\section{1. 연구대상 및 자료수집}

대한민국에 거주하는 19 세 이상 65 세 미만 성인을 대상으로, 식 용 곤충 이용 식품의 인지도 및 섭취 실태에 대한 설문조사를 실시 하였다. 본 연구는 대상자의 윤리적 측면을 고려하여 $\mathrm{K}$ 대학 생명 윤리심의위원회의 승인을 받아 수행되었다(KUIRB. 201811). 모든 대상자에게 연구목적과 비밀유지, 자발적 참여, 언제라도 철회 가능 하며, 연구목적으로만 사용되는 것을 설명하였다. 연구참여에 동의 한 대상자에게만 설문지를 배포하고 지정 공간에서 면담을 통해 설 문지를 작성하고 대상자에게 소정의 선물을 제공하였다. 자료수집 기간은 2019년 3월에서 5월까지 약 3개월간 진행 되었으며, 설문 지는 총 400 부를 배포하였고 불충분한 자료 13 부를 제외한 387 부 (96.8\%)를 수거하여 자료분석에 이용하였다.

\section{2. 연구도구}

본 연구에 사용된 설문지는 전문가의 검토와 선행된 관련 연구
(Min et al., 2016; Jung et al., 2018)를 기초로 연구목적에 맞게 수정 보완하여 구성하였다. 설문지 구성은 표본의 일반적인 특성 9 문항, 식용곤충에 대한 인식에 대한 5 문항, 식용곤충 섭취 유경험 자 대상 5 문항, 식용곤충 섭취 무경험자 대상 5 문항, 식용곤충 인 식개선 식생활교육프로그램 개발에 대한 2 문항, 성별에 따른 식용 곤충산업에 대한 전망에 대한 1 문항으로 구성되었다. 일반적 특성 은 인구 통계학적 변인으로, 성별, 연령대, 혼인 여부, 직업, 가족 수, 최종 학력, 동거 자녀 유무, 그리고 거주지로 구성된 총 9문항 이었다. 식용 곤충에 대한 인식도 조사를 위한 설문내용은 식량자 원으로 식용 곤충이 대두되고 있다고 들어본 적이 있는가, 식약처 에서 식용 곤충으로 인정한 7 개의 곤충에 대해 알고 있는가, 식용 곤충의 영양가는 높을 것이라고 생각하는가, 식용 곤충이나 이용 식품을 섭취해본 적이 있는가에 대한 질문으로 구성되었다. 식용 곤충 섭취 경험 유무에 따라, 섭취 경험이 있는 사람에게는 섭취한 이유, 섭취해본 곤충의 종류, 섭취해본 식용 곤충이나 식용곤충식 품 형태, 구입한 경로, 섭취한 빈도에 대해 조사하였다. 섭취 경험 이 없는 사람에게는 섭취하지 않은 이유, 향후 섭취 의향, 향후 섭 취한다면 선호하는 식용 곤충 이용 식품의 형태 등에 대해 조사하 였다. 향후 식용 곤충의 인식 개선을 위한 교육 프로그램에 개발에 대한 질문내용으로는 식생활 교육을 통해 식용 곤충에 대한 이점을 알게 된다면, 식용 곤충에 대한 인식 개선과 소비에 긍정적인 영향 을 줄 것인가에 대해 묻는 내용으로 구성되었다. 그리고 성별에 따 른 식용곤충 산업 발전 동향에 대해 조사하였다.

\section{3. 자료 분석}

설문을 통해 수집된 자료에 대한 통계분석은 SPSS Statistics 24.0 (SPSS Inc., USA)을 사용하였다. 대상자의 일반 사항과 식용 곤충에 대한 인식과 경험은 빈도 분석(Frequency Analysis)을 실 시하였고, 성별에 따른 식용곤충 식품에 대한 인식은 $\chi^{2}$-test 및 독 립표본 $t$-test를 실시하였으며 성별에 따른 식용곤충 식품선택 속 선택속성 등에 대한 중요도 분석은 $t$-test를 실시하였으며 카이 제 곱(Chi-square)검증을 실시하였다.

\section{Results and Discussion}

\section{1. 응답자의 인구통계학적 특성}

전체 조사 대상자는 남자는 167 명(43.20\%) 여자는 220 명 (56.80\%)명이었으며 20세 이상 65세 미만 성인을 장년기(19-39 세), 중년기(40-59세), 노년기(60세 이상)의 세 그룹으로 분류한 결과(Kang et al., 2012) 장년기 167명으로 $46.80 \%$, 중년기 181 명(47.50\%), 노년기는 39명(10.10\%)으로 19-59세가 대부분 이었 다. 기혼자가 268명(69.30\%)으로, 미혼인 사람 119 명(30.70\%)보 다 횔씬 많았다. 대상자들의 직업은 임금근로자가 150 명(38.80\%) 
으로 가장 많았고, 주부 94 명(24.30\%), 자영업자 67명(17.30\%), 학생 45 명(11.60\%), 기타 27 명(7.00\%)이었다. 가족 수는 4 인 이 상 가족이 174 명 $(45.00 \%)$ 으로 가장 많았으며, 3 인 가족이 70 명 (18.10\%), 5 인 이상이 62명(16.00\%), 2인 가족이 49명(12.70\%), 1 인 가족이 31 명 $(8.00 \%)$ 으로 가장 적었다. 본 연구결과에서 4 인 가족이 가장 많았으나 충남대전지역 식용곤충 성인의 식용곤충에 대한 인식조사에서 4 인 가족이 $52.5 \%$ 이었다는 연구결과보다는 적 게 나타났다(Seo et al., 2018). 이는 본 연구는 서울과 수도권 거 주자가 많았던 것도 한 요인으로 사료된다. 대상자들의 최종 학력 은 대학(재학 중 포함) 졸업 이상이 236명(61.00\%), 대학원 졸업자 가 93 명 $(24.00 \%)$, 고등학교 이하 졸업자가 51 명(13.20\%)이었다.
동거 자녀가 있는 사람은 220 명(56.80\%)이었고, 없는 사람은 165 명 $(42.60 \%)$ 으로 조사되었다. 대상자들의 거주 지역은 서울이 180 명(46.50\%)으로 가장 많았고, 수도권이 108명(27.90\%)이었으며, 광역시는 42 명(10.90\%), 군, 읍, 면 39 명(10.10\%), 기타 거주자는 17 명 $(4.40 \%)$ 이었다. 건강에 관심이 있는 정도는 250 명(64.60\%)이 '관심이 있는 편이다'라고 대답했고, 93 명(24.00\%)이 '관심이 매우 많다' ,'관심이 없는 편이다'가 38 명 $(9.80 \%)$, '관심이 매우 없다'가 5 명(1.30\%)으로 대부분의 사람들이 건강에 관심이 있는 것으로 나 타났다(Table 1). 즉 대부분의 성인은 건강에 매우 관심이 있으며, 이는 성인기의 삶의 질은 건강이 가장 영향을 미친다는 연구와 같 은 경향을 나타내었다(Kang et al., 2012).

Table 1. General characteristics of the participants

\begin{tabular}{|c|c|c|c|}
\hline Variables & Characteristics & Frequency (N) & Percentages (\%) \\
\hline \multirow{2}{*}{ Sex } & Male & 167 & 43.20 \\
\hline & Female & 220 & 56.80 \\
\hline \multirow{3}{*}{ Age group } & 20-39 (Young adult group) & 167 & 46.80 \\
\hline & 40-59 (Middle aged group) & 181 & 47.50 \\
\hline & 60-64 (Older adult group) & 39 & 10.10 \\
\hline \multirow{2}{*}{ Marital status } & Married & 268 & 69.30 \\
\hline & Unmarried & 119 & 30.70 \\
\hline \multirow{5}{*}{ Occupation } & Salary men & 150 & 38.80 \\
\hline & Self-employed & 67 & 17.30 \\
\hline & Student & 45 & 11.60 \\
\hline & Housewife & 94 & 24.30 \\
\hline & Others & 27 & 7.00 \\
\hline \multirow{5}{*}{ Family members } & 1 & 31 & 8.00 \\
\hline & 2 & 49 & 12.70 \\
\hline & 3 & 70 & 18.10 \\
\hline & 4 & 174 & 45.00 \\
\hline & $>5$ & 62 & 16.00 \\
\hline \multirow{3}{*}{ Highest level of education } & High school or less & 51 & 13.20 \\
\hline & Undergraduate (include attending) & 236 & 61.00 \\
\hline & Graduate school or more & 93 & 24.00 \\
\hline \multirow{2}{*}{ Children (coresidence) } & Yes & 220 & 56.80 \\
\hline & No & 165 & 42.60 \\
\hline \multirow{5}{*}{ Residence } & Seoul & 180 & 46.50 \\
\hline & Capital area & 108 & 27.90 \\
\hline & Metropolitan city & 42 & 10.90 \\
\hline & District, Town, Subdivision & 39 & 10.10 \\
\hline & Others & 17 & 4.40 \\
\hline \multirow{4}{*}{ Health consciousness } & More concerned & 93 & 24.00 \\
\hline & Concerned & 250 & 64.60 \\
\hline & Less concerned & 38 & 9.80 \\
\hline & Unconcerned & 5 & 1.30 \\
\hline
\end{tabular}




\section{2. 식량자원으로서의 식용곤충에 대한 인식}

식량 자원으로 식용 곤충이 대두되고 있다고 들어본 적이 있는 지에 대해 묻는 질문에 '들어본 적이 있다' 311 명(80.40\%), '들어본 적이 없다' 76 명(19.60\%)으로, 대부분의 사람들이 식용 곤충에 대 해 들어본 적이 있는 것으로 나타났다. 이는 Seo et al. (2018)의 연 구결과와 비슷한 경향을 나타내었다. 식품의약품안전처에서 메뚜 기, 누에번데기, 백강잠, 갈색저거리유충(고소애), 쌍별귀뚜라미(쌍 별이), 흰점박이꽃무지유충(꽃벵이), 장수풍뎅이유충(장수애) 총 7 종을 식용곤충으로 인정하고 있다는 것을 알고 있는지에 대해 묻는 질문에는 '알고 있다' 133명(34.40\%), '모른다'가 254명(65.60\%) 이었다. 식용 곤충의 영양가에 대해 묻는 질문에는 '영양가가 높 을 것 같다' 337명(88.63\%)로, 높지 않을 것 같다 39 명(11.37\%) 보다 훨씬 많았다고 나타나 다른 연구결과와 유사한 경향을 나타 내었다(Seo et al., 2018). 식용 곤충식품 섭취 경험유무 대해서는 식용 곤충 이용 식품을 실제로 섭취해본 적이 있는 사람은 181 명 (46.80\%), 섭취해본 적이 없는 사람이 220 명 $(51.70 \%)$ 으로 나타났 다(Table 2).

\section{3. 식용곤충을 섭취하는 이유, 섭취하는 식용곤충의 종류 및 구입장소}

식용 곤충 섭취 경험이 있는 사람들은 식품 목적으로 먹은 사람 이 107명(59.12\%)으로 가장 많았고, 보충제(21명, $11.60 \%)$, 질병 예방이나 치료 목적(3명 1.66\%), 호기심(43명, $23.76 \%)$, 그 외의 기타 목적이 7 명 $(3.87 \%)$ 이었다. 섭취해본 식용곤충 종류로는 누에 번데기가 81명(44.75\%)으로 가장 많았다. 메뚜기 68명(37.57\%), 쌍별귀뚜라미 6 명(3.31\%), 밀웜 14 명(7.73\%), 흰점박이꽃무지유 충(꽃벵이) 20 명 $(11.05 \%)$ 로 나타났다. 이 같은 결과는 Kang 등의 연구에서 식용곤충 섭취 종류를 조사한 결과 번데기 섭취가 가장 많았다는 결과와 일치한다(Kang et al., 2017). 식용곤충 섭취형태 로는 건조식품 76 명 $(42.00 \%)$, 분말형태 11 명 $(6.08 \%)$, 가공식품 형태51명(28.18\%), 보충제 3명(1.66\%), 기타 형태가 40(22.10\%) 로 나타났다. 식용곤충을 섭취할 때 고려하는 요인은 맛, 형태, 냄 새, 식감 등 관능적인 면이 79 명(43.60\%)로 가장 많았으며, 위 생, 안전, 식품가공 과정 54명(29.70\%), 영양가 34명(14.90\%), 질
병예방이나 치료목적 12 명(6.70\%), 가격 12 명(6.70\%), 기타 7 명 (4.10\%) 등으로 나타났다. 이는 다른 연구에서 식용곤충섭취경험 자들이 식용곤충을 섭취할 때 관능적인 맛, 형태 등을 중요시한다 는 연구결과와 비슷한 경향을 나타내었다(Seo et al., 2018). 식용 곤충 섭취빈도는 식용곤충을 섭취해본 경험이 있어도 낮은 편이었 다. 식용곤충 구입은 백화점이나 마켓 등 35 명(19.33\%), 온 라인 쇼핑몰 9명(4.97\%), 곤충을 전문으로 취급하는 곳, 혹은 전시장 22 명(12.15\%), 카페나 레스토랑 19 명(10.50\%), 지인 등 비매장이 70 명(38.67\%)로 가장 많았다. 이는 다른 연구(Jung et al., 2018)에 서 대형마트를 선호한다는 결과와는 다른 경향을 나타내었다. 그러 나 식용 곤충을 먹어본 사람이라 할지라도 월 1 회 이하로, 식용 곤 충을 지금은 거의 안 먹는 사람이 114 명 $29.50 \%$ 를 차지했다(Table 3). 이는 소비자를 대상으로 식용곤충 섭취에 대해 조사한 결과 안 전이나 식용곤충 형태에 불편함 등 인식부족에 의해 과거에 섭취했 다 하더라도 현재 섭취하지 않는다는 연구결과와 유사한 경향을 나 타내었다(Lee \& Kang, 2019)

\section{4. 식용곤충을 섭취하지 않는 이유}

식용 곤충 섭취 경험이 없는 사람을 대상으로 조사한 결과 식 용곤충을 섭취하지 않은 가장 큰 이유는 굳이 먹을 필요를 못 느 껴서가 97명(44.09\%)으로 가장 많았고, 외형(색, 형태, 냄새, 식 감 등)이 불편해서 81 명( $36.82 \%)$, 가격이 만족스럽지 않아서 2 명 $(0.91 \%)$, 위생이나 안전에 대한 확신이 없어서 22 명(10.00\%), 기 타 18명(8.18\%)로 나타났다. 이들은 앞으로도 굳이 먹을 필요를 못 느낄 것 같다는 사람이 86 명 $(22.50 \%)$, 식용곤충의 장점에 대 해 알게 되면 섭취할 의향이 있다 49 명(22.27\%), 기회가 되면 섭 취하겠다 49 명 $(22.27 \%)$ 으로 나타나 식용곤충의 장점이나 긍정적 인 면에 대해 좋은 인식을 갖게 되면 섭취할 수 있는 가능성을 시 사하여 향후 식용곤충인식개선 식생활교육프로그램개발이나 홍보 등이 필요함을 시사하는 결과로 사료된다. 식용 곤충 이용 식품을 만약 먹는다면, 영양보충제 형태를 먹겠다고 답한 사람이 이들 중 110 명(50.00\%)으로 가장 많았으며, 스낵(쿠키, 에너지 바 등) 62 명 (28.18\%), 인스턴트 식품의 형태 16 명 $(7.80 \%)$, 그냥 깨끗하게 손

\section{Table 2. Awareness of edible insects}

\begin{tabular}{lccc}
\hline Variables & Characteristics & Frequency (N) & Percentages (\%) \\
Are you aware of edible insects? & Yes & 311 & 80.40 \\
& No & 76 & 19.60 \\
Are you aware of the 7 species of edible insects authorized & Yes & 133 & 34.40 \\
by the Korean Ministry of Food and Drug Safety & No & 254 & 65.60 \\
Do you think edible insects are nutritious? & Yes & 343 & 88.63 \\
Have you ever eaten edible insects & No & 181.37 & 46.77 \\
\hline
\end{tabular}


Table 3. Experience related to eating edible insects

\begin{tabular}{|c|c|c|c|}
\hline \multirow{2}{*}{ Variables } & \multirow{2}{*}{ Characteristic } & \multicolumn{2}{|c|}{ Not experienced edible insects } \\
\hline & & Frequency $(\mathrm{N})$ & Percentages (\%) \\
\hline \multirow{6}{*}{ Why did you eat insects? } & As food & 107 & $59.12 \%$ \\
\hline & As nutritional supplement & 21 & $11.60 \%$ \\
\hline & For treatment/prevention of diseases & 3 & $1.66 \%$ \\
\hline & Out of curiosity & 43 & $23.76 \%$ \\
\hline & Others & 7 & $3.87 \%$ \\
\hline & Total & 181 & $100.00 \%$ \\
\hline \multirow{6}{*}{$\begin{array}{l}\text { What type of edible insect did } \\
\text { you eat? }\end{array}$} & Silkworm pupa & 81 & $44.75 \%$ \\
\hline & Grasshopper & 68 & $37.57 \%$ \\
\hline & Gryllus bimaculatus & 6 & $3.31 \%$ \\
\hline & Mealworm & 14 & $7.73 \%$ \\
\hline & Cicada larva & 20 & $11.05 \%$ \\
\hline & Total & 12 & $100.00 \%$ \\
\hline \multirow{6}{*}{$\begin{array}{l}\text { What type of edible insect } \\
\text { (foods) did you eat? }\end{array}$} & Dried food & 76 & $42.00 \%$ \\
\hline & Powder & 11 & $6.08 \%$ \\
\hline & Processed foods & 51 & $28.18 \%$ \\
\hline & Supplements & 3 & $1.66 \%$ \\
\hline & Others & 40 & $22.10 \%$ \\
\hline & Total & 181 & $100.00 \%$ \\
\hline \multirow{7}{*}{$\begin{array}{l}\text { What was the main factor when } \\
\text { you selected edible insect } \\
\text { (foods)? }\end{array}$} & Appearance (flavor, type, smell, texture, etc) & 79 & $43.60 \%$ \\
\hline & $\begin{array}{l}\text { Sanitation, and safety (place of origin, manufacturing } \\
\text { process, etc) }\end{array}$ & 54 & $29.70 \%$ \\
\hline & $\begin{array}{l}\text { Nutritional value (protein supplement, high nutritional } \\
\text { value) and quality }\end{array}$ & 34 & $14.90 \%$ \\
\hline & Health care to prevent or cure disease & 12 & $6.70 \%$ \\
\hline & Price & 12 & $1.00 \%$ \\
\hline & Others & 7 & $4.10 \%$ \\
\hline & Total & 181 & $100.00 \%$ \\
\hline \multirow{7}{*}{$\begin{array}{l}\text { Where did you acquire edible } \\
\text { insect foods from? }\end{array}$} & Department store, big retailer, market, etc. & 35 & $19.33 \%$ \\
\hline & Online shopping & 9 & $4.97 \%$ \\
\hline & $\begin{array}{l}\text { Insect experience center, exhibition center, or event } \\
\text { hall }\end{array}$ & 22 & $12.15 \%$ \\
\hline & Cafe and restaurants & 19 & $10.50 \%$ \\
\hline & Acquaintance or non-store retailing & 70 & $38.67 \%$ \\
\hline & Others. & 25 & $14.80 \%$ \\
\hline & Total & 181 & $100.00 \%$ \\
\hline \multirow{7}{*}{$\begin{array}{l}\text { How often do you eat edible } \\
\text { insects? }\end{array}$} & Rarely (less than once a month) & 108 & $49.09 \%$ \\
\hline & Once a week & 4 & $2.21 \%$ \\
\hline & 2-3 three times a week & 5 & $2.76 \%$ \\
\hline & $>4$ times a week & 2 & $110 \%$ \\
\hline & Whenever necessary & 50 & $27.62 \%$ \\
\hline & Others & 12 & $6.23 \%$ \\
\hline & Total & 181 & $48.30 \%$ \\
\hline
\end{tabular}


Table 4. Inexperience related to edible insects

\begin{tabular}{|c|c|c|c|}
\hline \multirow{2}{*}{ Variables } & \multirow{2}{*}{ Characteristic } & \multicolumn{2}{|c|}{ Not experienced edible insects } \\
\hline & & Frequency $(\mathrm{N})$ & Percentages (\%) \\
\hline \multirow{6}{*}{$\begin{array}{l}\text { Why did not you eat } \\
\text { edible insects? }\end{array}$} & $\begin{array}{l}\text { Not comfortable with their appearance (color, types, } \\
\text { smell, etc.) }\end{array}$ & 81 & $36.82 \%$ \\
\hline & No need to have edible insects & 97 & $44.09 \%$ \\
\hline & Not satisfied with price & 2 & $0.91 \%$ \\
\hline & Not confident about sanitation, safety, etc. & 22 & $10.00 \%$ \\
\hline & Others & 18 & $8.18 \%$ \\
\hline & Total & 220 & $100.00 \%$ \\
\hline \multirow{5}{*}{$\begin{array}{l}\text { Will you have edible insects } \\
\text { in the future? }\end{array}$} & I am willing if I get a chance. & 49 & $22.27 \%$ \\
\hline & $\begin{array}{l}\text { I am willing if I acquire knowledge about their } \\
\text { benefits }\end{array}$ & 49 & $22.27 \%$ \\
\hline & I do not need to eat edible insects & 86 & $22.50 \%$ \\
\hline & I will never eat edible insects & 37 & $16.82 \%$ \\
\hline & Total & 220 & $57.10 \%$ \\
\hline \multirow{7}{*}{$\begin{array}{l}\text { What type of edible insect foods } \\
\text { do you prefer? }\end{array}$} & Snacks (cookies, bars, etc.) & 62 & $28.18 \%$ \\
\hline & Beverages & 11 & $5.60 \%$ \\
\hline & Supplements & 110 & $50.00 \%$ \\
\hline & Instant foods & 16 & $7.80 \%$ \\
\hline & Raw (cleaned and prepared) & 8 & $3.63 \%$ \\
\hline & Others & 13 & $6.50 \%$ \\
\hline & Total & 220 & $100.00 \%$ \\
\hline \multirow{5}{*}{$\begin{array}{l}\text { How do you view the prospect } \\
\text { of the edible insect industry? }\end{array}$} & Favorable & 108 & $49.09 \%$ \\
\hline & Unfavorable & 17 & $7.73 \%$ \\
\hline & I do not know & 94 & $42.73 \%$ \\
\hline & Others & 1 & $0.30 \%$ \\
\hline & Total & 220 & $100.00 \%$ \\
\hline
\end{tabular}

\section{Table 5. Awareness of edible insect nutrition education program}

\begin{tabular}{lccc}
\hline Variables & Characteristics & Frequency (N) & Percentages (\%) \\
\hline $\begin{array}{l}\text { Do you think nutrition education program } \\
\text { (like giving information about types and }\end{array}$ & Yes & 290 & $74.93 \%$ \\
$\begin{array}{l}\text { nutritional value) will be helpful to have } \\
\text { positive awareness or attitude on edible } \\
\text { nsects (foods)? }\end{array}$ & I do not know & 17 & $4.39 \%$ \\
$\begin{array}{l}\text { Do you think nutrition education program } \\
\text { (like giving information about types and }\end{array}$ & Total & 80 & $20.67 \%$ \\
$\begin{array}{l}\text { nutritional value) will be helpful to have } \\
\text { positive effect on edible insects (foods) } \\
\text { consumption? }\end{array}$ & Yes & 387 & $100.00 \%$ \\
\hline
\end{tabular}

Table 6. Response to the industrial development trend of edible insects by sex

\begin{tabular}{llrrrr}
\hline Variable & Characteristics & Male (N/\%) & Female (N/\%) & Total (N/\%) & $X^{2}(\mathrm{df})$ \\
& Favorable & $92(55.09)$ & $123(55.91)$ & $215(55.56)$ & \\
How do you view the prospects & Unfavorable & $15(8.98)$ & $39(17.73)$ & $54(13.95)$ & 19.01 \\
$\begin{array}{c}\text { of the edible insect industry? } \\
\text { Total }\end{array}$ & I do not know & $59(35.33)$ & $57(25.90)$ & $116(29.97)$ & $\mathrm{df}=3\left(P=0.000^{*}\right)$ \\
& Others & $1(0.60)$ & $1(0.45)$ & $1(0.52)$ & \\
\hline
\end{tabular}

${ }^{* * *} p<0.001$. 
보였다. 그러나 다른 연구에서 식용곤충 섭취 비경험자는 영양보충 제 형태로 섭취하겠다는 결과와는 유사한 경향을 나타내었다(Seo et al., 2018). 식용곤충이나 식용곤충이용 식품을 섭취하지 않는 사람도 식용 곤충 산업이 앞으로 발전할 것 같다고 응답한 사람이 108 명으로 전체의 $49.09 \%$, 그렇지 않을 것 같다 17 명 $(7.73 \%)$, 잘 모르겠다 94 명(42.73\%)로 나타나 식용곤충을 비록 섭취하지 않더 라도 식용곤충 산업발전 가능성에 대해서는 긍정적인 반응을 보여 향후 식용곤충 산업발전이나 식용곤충 식품개발전망 가능성을 보 여주는 결과로 생각된다(Table 4).

\section{5. 식용곤충 인식개선 식생활교육프로그램 개발에 대한 의견}

식용 곤충의 장점에 대한 정보를 주는 식생활 교육 프로그램이 개발된다면 식용 곤충에 대한 인식에 긍정적인 영향을 줄 것인가에 대한 질문에, 응답자의 대부분이(290명, $74.93 \%)$ '그렇다'라고 응 답했다. 또한, 284 명인 $73.39 \%$ 가 식용 곤충의 소비에도 긍정적인 영향을 줄 것이라고 응답하여 식용곤충 인식개선 식생활 교육프로 그램 개발이 필요하다고 사료된다(Table 5).

\section{6. 성별에 따른 식용곤충 산업발전 동향에 대한 반응}

식용 곤충의 산업 발전 동향에 대해 묻는 질문에 남자는 '발전할 것 같다'고 대답한 사람이 92 명(55.09\%), 여자는 123 명 $(55.91 \%)$ 으 로 비슷한 경향을 나타내었다(Table 6).

\section{Conclusion}

이상의 결과 향후 식량 자원으로 식용 곤충이 대두되고 있다고 응답한 사람이 311명(80.40\%), 모르는 사람이 76명(19.60\%)으로, 대부분의 사람들이 식용 곤충에 대해 인지하고 있었다. 식약처에서 식용으로 인정하는 식용곤충 7종의 인지여부는 133 명(34.40\%)이 알고 있으며, 254 명 $(65.60 \%)$ 이 모른다고 대답하여, 식약처가 식용 으로 인정한 식용곤충의 종류에 대해서는 정확히 모르고 있는 사 람이 훨씬 많았다. 식용 곤충의 영양가는 '높을 것 같다.' 343 명 (88.63\%), 높지 않을 것 같다 44 명(11.37\%)보다 훨씬 많았다. 식 용 곤충이나 식용곤충 이용 식품 유경험자는 181명(46.77\%)이었 고, 비경험자는 220 명 $(56.85 \%)$ 으로 비슷한 경향을 나타내었다. 식 용 곤충 유경험자 중 식품 목적으로 먹은 사람이 107명(59.12\%)으 로 가장 많았고, 특히 누에번데기를 먹어본 사람이 81명(44.75\%) 으로 가장 많았다. 섭취한 식용 곤충이나 식용곤충 이용 식품의 형 태는 건조된 식용 곤충 76 명(42.00\%)이 가장 많았다. 식용 곤충이 나 식용곤충 이용 식품을 선택할 때 고려하는 요인은 맛, 형태, 식 감 등 관능적인 면이 79 명(43.60\%)으로 가장 많았다. 식용곤충 비 경험자는 외관이나 형태 등이 불편해서 81 명 $(36.82 \%)$, 굳이 섭취 할 필요를 느끼지 못해서가 97 명(44.09\%)으로 나타났다. 그러나
향후 식용곤충의 장점에 대해 알게 되고 기회가 된다면 섭취하겠다 고 한 사람이 $44.77 \%$ 로 나타나 향후 식용곤충에 대한 인식개선관 련 방안이나 식생활교육프로그램 등이 필요함을 시사하고 있다. 한 편 식용곤충 인식개선 식생활교육프로그램 개발은 '식용 곤충에 대 한 인식을 개선시킬 것이다' 290 명 $(74.93 \%)$, 식용 곤충의 소비에도 긍정적인 영향을 줄 것이라고 응답한 사람이 284 명 $(73.39 \%)$ 이었 다. 식용 곤충산업 발전 가능성에 대한 견해는 남자는 발전할 것 같 다라고 응답한 사람 92 명(55.09\%)이었고, 여자는 123명 (55.91\%) 이었다. 이상의 결과 향후 식용곤충 인식개선을 위한 식생활교육프 로그램이 개발되고 여러 가지 소비를 촉진시킬 수 있는 방안이 제 안된다면 미래 식량자원이자 대체 단백질 공급원으로 대두되고 있 는 식용곤충과 식용곤충 이용 식품의 상용화와 산업화에 크게 기여 할 것으로 기대되는 바이다.

\section{Acknowledgements}

본 연구논문은 한국연구재단 지원사업에 의해 수행되었습니다 (과제번호 2018071965).

\section{Author's contribution}

JSH designed, performed study, interpreted data, and wrote the manuscript. JSH and YKK designed survey. YJK performed analyzed statistics program. All tables are created by the authors and the corresponding author.

\section{Author details}

Youn-Jung Kim (Graduate student), Department of Human Ecology, Korea University, 145 Anamro, Seongbuk-gu, Seoul 02841, Korea; Yookyung Kim (Professor), Department of Home Economics Education, College of Education, Korea University, 145 Anamro, Seongbuk-gu, Seoul 02841, Korea; Jung-Soon Han (Research Professor), Research Institute of Human Ecology, Korea University, 145 Anam-ro, Seongbuk-gu, Seoul 02841, Korea.

\section{References}

Alston JM, Beddow JM, Pardey PG. Agriculture. agricultural research, productivity, and food prices in the long run. Science, 325: 1209-1210, 2009.

Arsenault JE, Brown KH. Effects of protein or amino-acid supplementation on the physical growth of young 
children in low-income countries. Nutrition Reviews, 75: 699-717, 2017.

Chong HS, Kim SY, Cho SR, Park HI, Baek JE, Kuk JS, Suh $\mathrm{HJ}$. Characteristics of quality and antioxidant activation of the cookies adding with mealworm (Tenebrio molitor) and black bean powder. Journal of Food Hygiene and Safety, 32: 521-530, 2017.

Chung MY, Kwon EY, Hwang JS, Goo TW, Yun EY. Pretreatment conditions on the powder of Tenebrio molitor for using as a novel food ingredient. Journal of Sericulture Entomological Science, 51: 9-14, 2013.

Hegsted DM, Ausman LM, Johnson JA, Dallal GE. Dietary fat and serum lipids: an evaluation of the experimental data. The American Journal of Clinical Nutrition, 57: 875-883, 1993.

Hwang SY, Choi SK. Quality characteristics of muffins containing Mealworm (Tenebrio molitor). Culinary Science \& Hospitality Research, 21: 104-115, 2015.

Jung JH, Lim BK, Bae SJ. Study on consumers perception of edible insect foods. Journal of Korean society Food Culture, 33: 558-566, 2018.

Kang MS, Kim MJ, Han JS, Kim AJ. Fatty acid composition and anti-inflammatory effects of the freeze dried Tenebrio molitor Larva. The Korean Journal of Food and Nutrition, 30: 251-256, 2017.

Kang MK, Kim MS, Gang MH, Oh KO, Kwon JS, Lee SH. Factors affecting the mental health related quality of life in adults across the lifespan. Korean Journal of
Rehabilitation Nursing, 15: 73-82, 2012

Kim HM, Kim JN, Kim JS, Jeong MY, Yun EY, Hwang JS, Kim AJ. Quality characteristics of patty prepared with mealworm powder. The Korean Journal of Food and Nutrition, 28: 813-820, 2015.

Kim SH, Kim KB, Noh JS, Yun EY, Choi SK. Quality characteristics of pasta with addition of mealworm (Tenebrio molitor). FoodService Industry Journal, 10: 5564, 2014.

Lee JT, Kang KO. A study on popularization and vitalization of edible insect by changing consumer perceptions and developing recipes: focus on college students in Seoul. Food Service Industry Journal, 15: 49-68, 2019.

Min KT, Kang MS, Kim MJ, Lee SH, Han JS, Kim AJ. Manufacture and quality evaluation of cookies prepared with mealworm (Tenebrio molitor) powder. The Korean Journal of Food Nutrition, 29: 12-18, 2016.

$\mathrm{Na}$ EJ, Jang HH, Kim GR. Review of recent studies and research analysis for anti-oxidant and anti-aging materials. Asian Journal of Beauty and Cosmetology, 14: 481-491, 2016.

No JK. A study of the sarcopenic obesity in aging. Asian Journal of Beauty and Cosmetology, 8: 139-148, 2010.

Seo JH, Park JY, Jeon MJ, Cho YI, Jeon MS. Perception and selection attributes of edible insects intake in adults in Daejeon and Chungnam are. Culinary Science \& Hospitality Research, 24: 170-182, 2018. 


\section{국문초록}

\section{성인의 식용곤충과 식용곤충 식품에 대한 인식}

김윤정 ${ }^{1}$, 김유경 ${ }^{2}$ 한정순 ${ }^{*}$

${ }^{1}$ 고려대학교 생활과학과, 서울, 한국

${ }^{2}$ 고려대학교 사범대학 가정교육과, 서울, 한국

${ }^{3}$ 고려대학교 생활과학연구소, 서울, 한국

목적: 본 연구는 국내에 거주하는 성인 남녀를 대상으로 식용곤충과 식용곤충 이용 식품에 대한 인식을 조사하여 향후 식용곤충 인 식개선을 위한 식생활교육프로그램 개발연구의 기초자료로 활용하고자 수행되었다. 방법: 대한민국에 거주하는 20세 이상 65 세 미만 성인 387명을 대상으로, 식용 곤충과 식용곤충 이용 식품 인식에 대한 설문조사를 실시 하였다. 자료 분석은 SPSS Statistics 24.0 통계 프로그램을 사용하였다. 대상자의 일반 사항과 식용 곤충에 대한 인식과 경험은 빈도 분석(frequency analysis)을 사용하 였고, 교차분석(cross tabulation analysis)과 카이 제곱(Chi-square) 검증을 사용하였다. 결과: 식량 자원으로 식용 곤충이 대두되 고 있다 311명(80.40\%), 그렇지 않다 76명(19.60\%)으로 대부분의 사람들이 식용 곤충이 미래 식량자원으로 인지하고 있었다. 식용 곤충의 ‘영양가가 높을 것 같다’ 343 명(88.63\%), 높지 않을 것 같다 44 명(11.37\%)보다 횔씬 많았다. 식용 곤충이나 식용곤충 이 용 식품의 섭취경험이 있는 사람은 181 명(46.77\%), 섭취경험이 없는 사람은 220 명(56.85\%)으로 나타났다. 식용곤충 섭취유경험자 는 식품 목적으로 섭취한 사람이 107명(59.12\%)으로 가장 많았고, 섭취한 식용곤충의 종류로는 누에번데기를 섭취해본 사람이 81 명(44.75\%)으로 가장 많았다. 식용곤충이나 식용곤충 이용 섭취 형태는 건조된 식용 곤충 76 명(42.00\%)으로 가장 많았다. 식용곤충 비경험자는 외관이나 형태 등이 불편해서 81명(36.82\%), 굳이 섭취할 필요를 느끼지 못해서가 97 명(44.09\%)으로 나타났다. 식용곤 충 인식개선 식생활교육프로그램 개발은 '식용 곤충에 대한 인식을 개선시킬 것이다' 290 명 $(74.93 \%)$, 또한 식용 곤충의 소비에도 긍 정적인 영향을 줄 것이라고 응답한 사람이 284명(73.39\%)이었다. 식용 곤충산업 발전 가능성에 대한 견해는 남자는 발전할 것 같다 라고 응답한 사람 92명(55.09\%)이었고, 여자는 123 명(55.91\%)이었다. 결론: 본 연구결과는 향후 식량자원으로 대두되고 있는 식용 곤충의 상용화와 산업화를 위해서 식용곤충 인식개선을 위한 다각적인 방안과 식생활교육프로그램의 개발이 필요함을 시사하는 것 으로 사료된다.

핵심어: 식용곤충, 식용곤충 식품, 인식, 성인, 식용곤충인식개선, 식생활교육프로그램

본 연구논문은 한국연구재단 지원사업에 의해 수행되었습니다(과제번호 2018071965).

\section{참고문헌}

강미경, 김명숙, 강문희, 오경옥, 권종선, 이선현. 성인의 생애주기별 정신건강 관련 삶의 질 영향요인. 재활간호학회지, 15: 73-82, 2012.

강미숙, 김민주, 한정순, 김애정. 동결건조 갈색거저리 유충의 지방산 조성과 항염증 효과. 한국식품영양학회지, 30 : 251-256, 2017.

김수희, 김기쁨, 노재승, 윤은영, 최수근. 갈색거저리를 첨가한 파스타의 품질특성. 한국외식산업학회지, 10: 55-64, 2014

김형미, 김정남, 김진수, 정미영, 윤은영, 황재삼, 김애정. 갈색거저리 유충 분말을 이용한 패티 제조 및 품질 특성. 한국식 품영양학회지, 28: 813-820, 2015.

나은주, 장현희, 김규리. 자연유래 항산화 원료와 제품개발을 위한 항산화 및 항노화 연구의 최신동향. 아시안뷰티화장품 학술지, 14: 481-491, 2016. 
노재경. 노화과정에서 저근육형 비만에 대한 이론적 연구. 아시안뷰티화장품학술지, 8: 139-148, 2010.

민경태, 강미숙, 김민주, 이선희, 한정순, 김애정. 갈색거저리 유충 분말을 이용한 쿠키 제조 및 품질평가. 한국식품영양학 회지, 29: 12-18, 2016.

서지희, 박지연, 전민지, 조영인, 전미선. 대전 및 충남지역 성인의 식용곤충에 대한 인식 및 선택속성. Culinary Science \& Hospitality Research, 24: 170-182, 2018.

정미연, 권은영, 황재삼, 구태원, 윤은영. 갈색거저리의 식품 원료화를 위한 분말제조 조건 확립. 한국잠사곤충학회지, $51:$ 9-14, 2013.

정희선, 김수연, 조성륜, 박현일, 백지은, 국지수, 서희재. 식용 밀웜 분말(Tenebrio molitor)과 검은콩 분말을 첨가한 쿠 키의 품질특성 및 항산화 활성. 한국식품위생안전성학회지, 32: 521-530, 2017.

황수영, 최수근. 밀웜(갈색거저리) 분말 첨가 머핀의 품질 특성. 한국조리학회지, 21: 104-115, 2015. 


\section{中文摘要}

\section{成人对食用昆虫和昆虫食品的认知}

金允廷 ${ }^{1}$, 金有京 $^{2}$, 韓正順 $^{3 *}$

高丽大学生活科学科, 首尔, 韩国

2 高丽大学师范大学家政教育科, 首尔, 韩国

高丽大学生活科学研究所, 首尔, 韩国

目的：本研究旨在调查韩国成人对食用昆虫和昆虫食品的认知，并将此项发现作为项目开发研究的基础数据，以 提高对食用昆虫的认知。方法: 对居住在韩国的387名21-64岁成人进行调查。数据分析采用SPSS统计24。采用 频数分析、卡方检验等方法，对食用昆虫的感知和体验进行分析。结果：共有311名参与者（80.40\%）回答食用 昆虫正在成为食物来源, 大多数人意识到食用昆虫作为未来食物来源的潜力。了解食用昆虫的参与者可能为 311 人 (80.40\%)，而不了解食用昆虫的参与者可能 279 人（19.60\%）。此外，181名参与者（46.77\%）食用过昆 虫，220名参与者（56.85\%）从未食用过昆虫食品。以食用昆虫为食的参与者有 107 人（59.12\%），其中 81 人 （44.75\%）食用过蚕蛹。在选择食用昆虫时，参与者认为感官评估很重要。结论: 食用昆虫作为未来的食物资 源，其商品化和产业化需要发展饮食教育项目，提高食用昆虫的认识。

关键词: 食用昆虫, 认知, 成人，食用昆虫食品，饮食教育计划 
